\title{
Una Audiencia para el septentrión americano, suprimir o no la Audiencia de Guadalajara
}

\author{
Alfredo José Orozco Martín del Campo*
}

\section{INTRODUCCIÓN}

La visita a la Audiencia se "propuso" en 1635 por cédula al Marqués de Cadereyta, esto debido a que el rey se enteró de "[...] los grandes excesos que cometen en la administración de ella los oidores de mi Audiencia Real de Guadalajara y demás ministros [...]". ${ }^{1}$ Además, se ordenó especialmente que se informara si convenía quitar la Audiencia, por lo que le ordenó al Marqués que informara sobre "[...] los pleitos que se tratan en ella, de qué calidad y cantidad son y si las apelaciones se podrían seguir en esa Audiencia de México y me informéis sobre todo y si será bien consumirla, y me daréis las causas que de haber para ello, y cómo se podrá disponer el gobierno de aquella provincia y el distrito que tiene, o si sería mejor conservarla". ${ }^{2}$

Sin embargo, ésta se retrasó por la muerte del oidor al cual se encomendó en primera instancia, el entonces oidor de México, Pedro de Quiroga y Moya, así como por las inundaciones que sufrió la Ciudad de México desde el año 1629. La visita se demoró hasta el año 1637 y se le encargó al oidor Francisco de Rojas, quien acababa de regresar de hacer otra a la también Audiencia de Filipinas. Llegó el dicho oidor a Guadalajara a principios del mes de febrero de 1638, y su primera acción fue la publicación de los edictos de la visita, tanto en la ciudad Guadalajara, como por el distrito de la Audiencia.

De pocas visitas a la Audiencia de Guadalajara tenemos noticia; parece que la inspección de 1566 a Nueva España, encomendada a Jerónimo de Valderrama, incluía la Audiencia de Nueva Galicia; al menos se le comisionó

* El Colegio de Jalisco, Jalisco, México. Correo electrónico: alfredojose84@yahoo.com

1 Carta del rey al Marqués de Cadereyta virrey gobernador y capitán general de la Nueva España del 8 de octubre de 1635, en "Cartas de autoridades civiles y eclesiásticas, consultas, decretos, etc., relacionados en el Consejo sobre la conveniencia de suprimir la Audiencia de Guadalajara". AGI, GUADALAJARA, 10, R.4, N.19.

2 Ídem. 
para visitar a los oficiales reales. La de 1583 de Pedro Moya de Contreras y terminada por Diego Romano también debió de incluir la Nueva Galicia, pero no hay noticia de su presencia en la Audiencia. ${ }^{3}$

\section{Antecedentes}

¿Por qué se ordenó una visita a la Audiencia de Nueva Galicia? De la carta se desprende que fue por los excesos que cometían los oidores. Para entender cuáles fueron dichos excesos habría que analizar el contexto de la Audiencia hacia 1635, y es que, a más de diez años desde la muerte del Presidente Otarola, en la Audiencia no había conformidad. Esto se debió a que la Audiencia quedó con la presidencia vacante por casi cinco años bajo la dirección, y no el mando, del licenciado Bartolomé de la Canal, uno de los primeros criollos en ser nombrado oidor. Hombre ya muy mayor, al decir de las cartas y memoriales, De la Canal sumió a la Audiencia en una especie de letargo en que nada se hacía y los problemas que dicha institución tenía no iniciaron hasta bien entrado el año 1632 .

Fue el Marqués de Cerralbo quien dio aviso de la llegada del nuevo presidente de Guadalajara diciendo que "[...] el presidente Morquecho ha llegado ya, pero viejísimo y muy impedido de la gota y achaque, hace lo que puede, pero no puede nada [...]". ${ }^{4}$ Pero los demás oidores no eran tan jóvenes tampoco. Diez años antes el presidente Otarola, al informar sobre los mismos oidores (que no cambiaron en más de diez años) decía sobre ellos que

[...] el oidor más antiguo es el licenciado, Bartolomé de la Canal [...] paréceme tendrá cincuenta y ocho años [en realidad tenía 62]. [...] El segundo en ellos es el licenciado don Diego de Medrano a diez años que sirve, será de hasta treinta seis años [...]. El tercero es el licenciado Gaspar Chávez [...] tendrá cincuenta y seis [...]. El último en orden es el licenciado don Antonio de Villacreses será de hasta cincuenta y ocho años [en realidad tenía 62$].^{5}$

Es decir, se trata de una Audiencia ya muy mayor, ya que el más joven de los oidores era el licenciado Medrano, que tendría ya unos 50 años, mientras que sus homónimos pasaban todos de los 70; por tanto, no es raro que en las mencionadas cartas y consultas abunden las quejas sobre ella y sus ministros.

3 Pilar Arregui Zamorano, La Audiencia de México según los visitadores (siglos XVI y XVII), México, unAm, 1985, p. 65.

4 Carta del Marqués de Cerralbo al rey, en "Cartas de autoridades civiles y eclesiásticas, consultas, decretos, etc., relacionados en el Consejo sobre la conveniencia de suprimir la Audiencia de Guadalajara", AGI, GUADALAJARA, 10, R.4, N.19.

5 Carta del licenciado Pedro de Otárola al rey de 6 de mayo de 1622, AGI, GUADALAJARA, 9, R.2, N.3. 
Estas quejas y excesos versan principalmente en tres materias concretas: 1) que entre ellos no se ponían de acuerdo, situación que se agravó con el nuevo presidente; 2) que no querían hacer las visitas al reino; $y$, finalmente y de forma menos concreta, 3) favorecer a sus allegados.

Entre la correspondencia de los oidores y del presidente se puede llegar a ver el trasfondo del pleito; nos dice Mota Padilla que el doctor D. Diego Núñez y Morquecho era "[...] natural de Pancorbo en Castilla la Vieja, quien había sido alcalde de corte en México, y oidor en Lima, de donde le sacó su Majestad para Presidente de la real Audiencia y gobernador del reino de la Nueva Galicia, era de crecida edad, por lo que gobernó solo tres años [...]"'. ${ }^{6}$

El carácter del licenciado Núñez Morquecho se deja ver ya desde una de las primeras cartas que remitió, en las cuales se quejaba del nepotismo de los oidores, puesto que entre otras cosas afloraron situaciones que por desidia se dejaron de hacer $\mathrm{y}$, a falta de presidente, se empezaron a otorgar cargos a familiares de los oidores (cosa no poco frecuente, como es el caso del hermano del licenciado Medrano, al que se le otorgó un corregimiento). Asimismo, no se mandaban informes y no se suspendía a otros funcionarios, como el caso del corregidor de Zacatecas, a quien el presidente señalaba como "enfermo y loco" y que entre otras cosas tenía sin salir de su casa más de dos años. ${ }^{7}$

En una carta del 20 de junio de 1629, relataba el doctor Morquecho cómo “[...] entre sí los oidores están tan encontrados que admiten las recusaciones y salen con ellas y esto no me espanta tanto como que en esta Audiencia se admitieren recusaciones de unos oidores contra otros sin más diligencias que el juramento de cualquiera de ellos y de sus deudos [...]". ${ }^{8}$

Si se examina el acervo del archivo de la Real Audiencia, es posible comprobar que el doctor tenía razón, ya que buena parte de los asuntos del siglo XVII que hoy se conservan son recusaciones. El doctor Morquecho agregaba que

[...] las recusaciones que en esta Audiencia se han hecho de los años a esta parte que fuera bien largo y bien notables de la manera que en ellas se ha precisado, pero como son negocios de acuerdo de la Audiencia, no me atrevo a sacarlo del, sin orden de vuestra majestad por el respeto que le debo a las cosas del Acuerdo y el riesgo que corre a que en un viaje tan largo se pierdan o hurten $[\ldots]^{9}$

6 Matías de la Mota Padilla, Historia del reino de Nueva Galicia en la América Septentrional, Colección Histórica de Obras Facsimilares 3, Guadalajara, IJAH-INAH, UDG, 1973, p. 801.

7 Carta del licenciado Núñez Morquecho al rey de 12 de junio de 1629, AGI, GUADALAJARA, 9, R.9, N.37.

$8 \quad$ Ídem.

9 Carta de la Audiencia de Guadalajara al rey de 22 de junio de 1629, AGI, GUADALAJARA, 9, R.9, N.40. 
El conflicto entre ambas partes no se dejó esperar, y el 29 de junio los oidores Medrano, Chávez y Villacreses escribieron una carta al rey..$^{10}$ Dicha carta es una magnífica descripción de la vida cotidiana de la institución, la cual nos muestra las peleas por el poder entre los oidores y el presidente. Señalaron los oidores en la misiva que, a poco más de un mes de la llegada del doctor Diego Núñez Morquecho, comenzó este a hacerles "[...] muchas demostraciones de desafición y desabrimiento con nosotros, nacido de que ha formado sentimiento diciendo que la Audiencia no envió persona a México para que lo recibiera y acompañara en el viaje, hasta llegar a esta ciudad [...]". ${ }^{11}$ Ellos se justificaron diciendo que todo fue muy apresurado, y agregaron el incidente que sucedió en catedral el primer día de Pascua al llegar a Guadalajara el doctor Morquecho. ${ }^{12}$

Dado lo anterior, entre otras cosas, los oidores y el presidente comenzaron con problemas de jurisdicción entre las labores de gobierno y justicia propias de la Audiencia, por lo que el doctor Morquecho ordenó que todo lo de gobierno lo viera sólo él, a lo que los oidores señalaron que "[...] cuando se ven en la Audiencia por apelación los autos de gobierno se exaspera con los oidores y con las partes y con sus abogados y agentes si dicen y alegan en contra de sus autos del gobierno//y aún se entromete el Presidente a conocer en gobierno de las cosas de justicia tocantes a la Audiencia $[\ldots]$ ". ${ }^{13}$ Relataron con coraje los oidores, haciendo alusión a sus jurisdicciones, que en los pleitos de justicia no los dejaba votar con libertad y los insultaba si no le obedecían. ${ }^{14}$

Además, realizaron señalamientos sobre el estado de salud del presidente y cómo se conducía, ya que tenía serios problemas de salud que le impedían realizar todas sus funciones y apenas si podía trabajar; por los mismos achaques bajaba tarde a la Audiencia y los hacía esperar mucho tiempo, y lo mismo sucedía en la capilla donde se decía misa. ${ }^{15}$ Esto confirma cómo los oidores deseaban establecer sus propias jurisdicciones y que por el hecho de tener cierto tiempo solos se establecieron ciertos usos y costumbres que se trastocaron por la llegada del nuevo Presidente. Finalmente, los oidores señalaron " $[\ldots]$ cómo el dicho presidente muestra mucho disgusto de haber venido a esta Audiencia diciendo que daría diez mil pesos por no haber venido acá y que está arrepentido de haber aceptado la plaza [...]". ${ }^{16}$

Todo parece indicar que una de las razones de origen del problema era la edad de los ministros. De hecho, en el expediente se encuentra una serie de

9, R.9, N.41.

Ídem.

Ídem.

Ídem.

Ídem.

Ídem.

Ídem. 
cartas del presidente Morquecho quejándose de que nadie quería hacer la visita del reino desde hacía nueve años.

Sin embargo, junto con las cartas del presidente aparecen las excusas de los oidores para no hacer la visita; así, el licenciado Medrano se excusó señalando que muchas veces hacía sala solo, ya que estaba el "[...] presidente tan impedido y tullido del mal de gota y vejez que en una silla de manos lo suben dos negros a los reales estados hasta emparejar con ellos y con él el bufete donde se libran los pleitos, y hasta el Real Acuerdo entrando en la dicha silla en la sala donde se sube hasta tomar su asiento [..] $;^{17}$ a esto agregó que él no se negaba a hacer la visita, pero que de momento estaba recién casado "[...] con doña Ana Gallardo, de edad de trece años, y al presente estar mala y achacosa de preñado y habiendo de ser forzoso dejarla corría riesgo su vida $[\ldots]^{\prime \prime}{ }^{18}$

El licenciado Antonio de Villacreces, a la razón de más de 70 años, dio cuenta de que, además de su avanzada edad “[...] está enfermo del mal de la orina, y por este achaque se ha escusado muchas veces de salirse de la Audiencia [... $]$ ". ${ }^{19}$ Finalmente, el licenciado Gaspar de Chávez y Sotomayor, quien había estado por más de veintitrés años en Guadalajara, se excusó con una carta que rubricó el médico de la ciudad, el licenciado Tomás de Acevedo, el cual certifica y da fe de los distintos males que padecía el viejo oidor

[...] unas almorranas que le apuran con estreno y por estar como está el dicho señor oidor quebrado de las verijas que se le salen las tripas algunas veces y de ventosidades que le ponen a punto de muerte como lo ha estado estos días, y con los dichos males asimismo le apuran unas seguidillas de cámaras y otros males y su mucha edad y gran flaqueza [que a él] le parece que si el dicho señor oidor se pusiese en camino sería con muy gran riesgo de su vida, y a riesgo de que yendo a caballo salírsele las tripas y quedase muerto $[\ldots]^{20}$

También cabe agregar que seguía vacante la plaza del finado licenciado Bartolomé de la Canal, por tanto, ni las visitas se podían hacer ni muchas veces se podía realizar el Acuerdo, por no haber cuórum. Fueran verdad o no

17 Carta del licenciado Medrano al rey, en "Cartas de autoridades civiles y eclesiásticas, consultas, decretos, etc., relacionados en el Consejo sobre la conveniencia de suprimir la Audiencia de Guadalajara", AGI, GUADALAJARA, 10, R.4, N.19.

18 Ídem.

19 Carta del licenciado Antonio de Villacreces al rey, en "Cartas de autoridades civiles y eclesiásticas, consultas, decretos, etc., relacionados en el Consejo sobre la conveniencia de suprimir la Audiencia de Guadalajara”, AGI, GUADALAJARA, 10, R.4, N.19.

20 Carta del licenciado Gaspar de Chávez y Sotomayor, y de su médico el licenciado Tomás de Acevedo al rey, en "Cartas de autoridades civiles y eclesiásticas, consultas, decretos, etc., relacionados en el Consejo sobre la conveniencia de suprimir la Audiencia de Guadalajara", AGI, GUADALAJARA, 10, R.4, N.19. 
las enfermedades de los oidores, éstos murieron al poco tiempo: el licenciado Medrano el 16 de junio de 1630 y le siguió el licenciado Chávez el 31 de octubre del mismo año, por lo cual quedaron solos el viejo presidente con el otro viejo oidor, Villacreces.

Ya para esas fechas, concretamente el 31 de marzo de 1631, escribió el virrey Marqués de Cerralbo quejándose de ello, diciendo cómo en Guadalajara había grandes encuentros entre el licenciado Diego Núñez Morquecho y don Antonio de Villacreces, oidor, y cómo ambos le escribieron; y como él se encontraba sin jurisdicción para dar las órdenes precisas, sólo pudo decir lo que sentía. Afirmó el virrey que "[...] por ahí tienen poco que hacer y se entretienen con discordias, que no han faltado desde que yo estoy en la nueva España" y terminó opinando que lo mejor era quitar la Audiencia. ${ }^{21}$

Poco tiempo después también murió el licenciado Morquecho, en enero de 1632, y luego el licenciado Villacreces, el 3 de enero 1633. Durante ese año las cartas remitidas a España apenas si eran firmadas por el antiguo fiscal, el doctor Damián Gentil de Parraga, quien fue nombrado oidor. De esta forma, la institución quedó casi acéfala hasta la llegada, a finales de 1632, de los nuevos oidores, el doctor Antonio de Salazar y el licenciado Francisco de Medrano y Pacheco.

En la carta en que se anuncia la muerte del presidente Morquecho, el decano de la Audiencia relató el estado en que ésta se encontraba. En ella se muestra un panorama de desidia y poca diligencia, ya que, según el doctor Damián Gentil de Parraga, desde los tiempos del licenciado Canal no se hacían ni aplicaban las reales cédulas (bien lo había de saber él, que fue el fiscal, y por ello encargado de presentarlas), ya que tanto él como sus sucesores por desidia no aplicaron las cédulas remitidas por su majestad, por lo que él lo hacía en cumplimiento de su deber. Señaló además que tampoco se había hecho la visita del reino, y que, si bien le toca a él por turno, tras largas pláticas con el obispo decidieron juntos que no era conveniente que él, por ser el decano, fuere a hacer la visita, por lo que se le encomendó tal tarea al oidor Medrano. Finalmente, dio noticia de una epidemia de peste en los pueblos indígenas circunvecinos a la ciudad de Guadalajara, por lo que se procedió a mandar a un médico, cirujanos y medicinas para su socorro. ${ }^{22}$

21 Carta del Marqués de Cerralbo al rey de 31 de marzo de 1631, en "Cartas de autoridades civiles y eclesiásticas, consultas, decretos, etc., relacionados en el Consejo sobre la conveniencia de suprimir la Audiencia de Guadalajara", AGI, GUADALAJARA, 10, R.4, N.19.

22 Carta del doctor Damián Gentil de Parraga al rey de 28 de febrero de 1633, en "Cartas de autoridades civiles y eclesiásticas, consultas, decretos, etc., relacionados en el Consejo sobre la conveniencia de suprimir la Audiencia de Guadalajara", AGI, GUADALAJARA, 10, R.4, N.19. 
A su vez, la Audiencia escribió al rey el 28 de febrero de 1633 informando la muerte del presidente y del licenciado Villacreces, que estando destinado a Santo Domingo esperaba su título. Se informó también sobre la plaga (todo indica que de tifus) y de todo lo que se estaba haciendo para ayudar a los indígenas. Asimismo, en anticipación de que se mandara un nuevo presidente, pidió cédula para que éste no pudiera prender a los oidores y aludió al caso del doctor Morquecho, quien prendió al licenciado Villacreces. De este modo se manifestó la autonomía judicial de la Audiencia frente al presidente, ya que, como señalaron los oidores, esto era " $[. .$.$] en prejuicio del bien público,$ y aunque hay algunas cédulas en que sí han dado prevenciones a los dichos presidentes por sucesos semejantes y se dice en ellas que no lo pueden hacer si no en ciertos casos $[\ldots]^{3} .{ }^{23}$

En ese mismo año se nombró como presidente de Nueva Galicia a otro oidor de Lima, Alonso Pérez de Salazar y Rosales, quien declinó, mediante carta de 8 de marzo de 1634, en los Reyes. El licenciado Pérez de Salazar y Rosales señaló que no podía hacer el viaje a Guadalajara por su crecida edad (62 años), además de sus muchos achaques y del hecho de que en su casa aún tenía hijos e hijas, por lo que en atención a su deber como buen padre debía buscarles un buen partido y ayudar a establecerlos. ${ }^{24}$

Así las cosas, al tiempo de la visita (casi nueve años después) se entiende por qué el virrey pidió al visitador que se concentrara en la segunda parte de la cédula, y no en los agravios de los ministros, ya que procuró

[...] enviar visitador no tanto por el castigo de los excesos en lo particular, que ya los más de ellos son muertos, como por buscar la enmienda para en lo de adelante y lo principal, el ajustar con toda precisión lo que mira a si se ha de consumir o no a aquella Audiencia y la forma en que será mejor al gobierno de la provincia y por muerte de don Francisco de Quiroga, nombre al licenciado Francisco de Rojas y Oñate $[\ldots] .{ }^{25}$

Así, debido a que para estas fechas no quedaba ningún oidor vivo de aquellos inculpados, la visita estuvo enfocada ya no en castigar e informar de los excesos de los ministros, sino en evaluar la viabilidad de la institución.

\section{LA VISITA}

Para la época que nos ocupa, la primera mitad del siglo XVII, la visita no era una entidad del todo regulada. Si bien existió, no aparece regulada en

23 Ídem.

24 Carta del licenciado Pérez de Salazar y Rosales al rey de 8 de marzo de 1634, AGI, GUADALAJARA, 9, R.14, N.58.

25 Cuaderno de cartas remitidas por el marqués de Cadereyta, AGI, MÉXICO, 34, N.21. 
ningún ordenamiento castellano ni en la literatura jurídica de la época, independientemente de que en ellos sí se mencione. Sin embargo, pareciera que existe una confusión entre visita y residencia, como señalan Sánchez Bella $^{26}$ y Miguel Malagón Pinzón. ${ }^{27}$

La figura del juez visitador apareció desde $1371,{ }^{28}$ pero fue hasta finales del siglo XVII que encontramos bien reguladas sus funciones. Es cierto que no se contó con un estilo para llevarlas a cabo hasta bien entrado el siglo XVII, en las Leyes de Indias de 1680 y en las llamadas "prácticas", como la de Pedro Pérez Landero Otáñez y Castro escrita en Nápoles en 1696. ${ }^{29}$

La presente investigación no abundará ni en el método ni en la legislación porque para la época no la hubo. Baste decir que sí hubo una serie de procedimientos para llevar a cabo las visitas. Los autores coinciden en que dicha tradición era eminentemente canónica, y que el procedimiento normalmente lo cumplían todos los visitadores. Sánchez Bella nos ofrece un buen sumario de éstos y nos muestra las distintas etapas y partes de las visitas llevadas en América en el siglo XVII. ${ }^{30}$

El designado para la visita fue el ya mencionado Francisco de Rojas y Oñate (bautizado en Madrid en el año de 1588) y oidor de México a partir del año de $1626 .{ }^{31}$ Volvía el funcionario de hacer la visita a la Audiencia de Filipinas, cuando se le nombró para esta comisión. Hombre de 50 años, se quejaba de su edad y sus continuos achaques provocados por el viaje a Filipinas; y aunque no fue él la primera opción para hacer la visita, finalmente fue el designado por el virrey, si bien trató de excusarse, en palabras del virrey, "[...] por haber casado a don Gabriel de Rojas su hijo con doña María de Sandoval nieta del licenciado Núñez Morquecho, presidente que fue de aquella Audiencia, hija de don Juan Mejía y sobrina de Francisco de Peralta, considerando los unos y los otros por comprendidos en ella y en particular a don Francisco y a los oidores Andrés Prado de Lago su compadre le tuviese por escusado [... ]". ${ }^{32}$

26 Ismael Sánchez Bella, "El juicio de visita en Indias”, IV Congreso del Instituto Internacional de Historia del Derecho Indiano, 1976, México, pp. 579-626.

27 Miguel Malagón Pinzón, "Las visitas indianas, una forma de control de la administración pública en el estado absolutista", Vniversitas, núm. 108, diciembre de 2004, pp. 821-838 https://www.redalyc.org/pdf/825/82510821.pdf [consultado el 1 de octubre de 2018].

28 Ídem.

29 Pedro Pérez Landero Otáñez y Castro, Práctica de visitas y residencias apropiada á los Reynos del Perú y deducida de lo que en ellos se estila, Nápoles, 1696.

30 Ismael Sánchez Bella, Derecho Indiano Estudios: Las visitas generales en la América española (siglos XVI-XVII), vol. I, Eunsa, 1991.

31 Javier Barrientos Grandon. Guía prosopográfica de la judicatura letrada indiana (15031898), Fundación Histórica Tavera, 2000.

32 Carta de Juan de Canseco y Quiñones al rey de 12 de julio de 1638, AGI, GUADALAJARA, 9, R.17, N.65. 
Pero, debido a que los involucrados ya habían muerto, y a que lo principal de la encomienda era la supervivencia o no de la Audiencia, sus excusas quedaron de lado; si bien estas excusas nos reafirman lo endogámica que fue la judicatura indiana. Llegó el señor visitador en febrero de 1638 y comenzó la visita; sin embargo, se topó con la oposición (nada rara) de los visitados, primeramente, con el recientemente nombrado presidente Canseco y Quiñones, quien se extrañó de la necesidad de la visita, ya que aparentemente el virrey no debió mandarla.

Esto fue lo que expresó el licenciado Canseco al relatar cómo, antes de salir de México, el virrey le mostró una cédula, la cual se le había entregado en Madrid, donde se le ordenaba mandar a visitar la Audiencia de Guadalajara. Sin embargo, ambos habían quedado de acuerdo en que primero el licenciado Canseco le avisaría cómo estaban las cosas, y como dio aviso de que todo se encontraba en paz y quietud, le extrañó mucho el envío del visitador, el cual sólo serviría para gastos y costas al rey y a su real hacienda. Aunado a ello, en la Audiencia sólo quedaban dos oidores y las dos viudas de los otros dos, lo señaló que eran pobrísimas razones para ser visitados. ${ }^{33}$

Juan de Canseco y Quiñones, natural de León, fue alcalde del crimen en México y oidor de la misma ciudad. Por ello, conoció las visitas efectuadas a México. Fue nombrado presidente de Guadalajara en enero de 1636, y sus argumentos para evitar la visita fueron principalmente de índole económico, si bien posteriormente intentó salirse de la jurisdicción del visitador. En palabras del licenciado Rojas:

Un día antes que publicase [la visita] ha venido a visitar el doctor don Juan de Canseco, presidente de la Audiencia, me propuso que él no debía ser visitado porque al tiempo que la cédula de la visita se hubo expedido en el consejo, aun no era electo presidente y se pasaron muchos días después que lo fue, y que tomó posesión de su plaza [...] y también porque las palabras de ellas no eran comprendido el presidente como superior, si no solo los inferiores, y sobre esto hizo ciertos apuntamientos en derecho que envió para moverme $[\ldots]{ }^{34}$

El hecho de que el presidente no quisiera ser parte de la visita no es extraño, sin embargo, los argumentos son los que parecen interesantes. En primer lugar, el hecho de que la visita no lo debía incluir porque se ordenó antes de que él fuera nombrado era el más fuerte de los argumentos, y si bien en un principio ni este argumento ni el segundo sobre el "significado" de lo que abarcaba la palabra audiencia fueron aceptados por el licenciado Rojas, éste escribió que

Ídem.

Carta de Francisco de Rojas oidor de la Audiencia de México y visitador de la Audiencia de Guadalajara al rey de 16 de febrero de 1639, AGI, GUADALAJARA, 9, R.18, N.72. 
[...] a mí me pareció más jurídica la contraria, y así le procuré satisfacer a ellos, con que la palabra Audiencia (a quien se mandaba visitar) comprendía en sí, todos los ministros, superiores e inferiores, y así de su naturaleza se deriva entender, tanto en el presidente como en los porteros de ella [...] y que aunque el tiempo que se despachó la cédula no lo era, bastaba que lo fuese cuando se determinó por el virrey a cuyo arbitro se dejó el que se hiciese, y se me nombró a mí para ello [...] no se allanó y por evitar encuentros, que pudieran resultar, nos convenimos en remitir la duda al virrey para que lo determinase y en el ínterin lo comprendí en el interrogatorio y pesquisa secreta como a los demás presidentes $[\ldots]{ }^{35}$

Al final, Rojas se avino a aceptar los argumentos del presidente, ya que, como señaló, "[...] remitirlo al consejo era embarazarme, de manera que antes de tener resolución se había de haber acabado la visita (como ha sucedido) y también porque tuve por tan llana mi opinión, que no juzgué se pudiera dejar de aprobar por el virrey [...]". ${ }^{36}$ Añadió posteriormente que el virrey " $[\ldots]$ no sé con qué motivos me ordenó que entretanto que vuestra majestad a quien se había de dar cuenta de la controversia mandaba otra cosa, suspendiese el visitar al presidente $[\ldots]$ ". ${ }^{37}$

Una vez resuelto el asunto del presidente y otras contradicciones hechas por el fiscal al virrey sobre su jurisdicción (al parecer la Audiencia no aceptó la jurisdicción del virrey para mandar una visita), el licenciado Rojas procedió con la visita, no sin antes imponerle una serie de multas al fiscal y al escribano por orden del virrey. Sin embargo, el único oidor que opuso una mayor resistencia a la visita fue el licenciado Francisco de Medrano y Pacheco, quien como oidor más antiguo tenía ciertas prerrogativas, por lo que interpuso una serie de recursos en contra del visitador, que, tras apelar y recusarle, acudió a la Audiencia para interponer un recurso, a lo cual el visitador anuló todo lo actuado por ésta. De tal modo, procedió el visitador señalando que "[...] la Audiencia estaba inhibida por cláusula de mi comisión, y que así, todo lo por ella proveído, era nulo, y solo el real consejo podía conocer en grado de apelación de mis actos, a donde lo remití y ejecuté lo que había determinado [...]". ${ }^{38}$ Lo único que logró el decano fue retrasar el proceso y, eso sí, quitar al escribano que el licenciado Rojas trajo de México por cierta acusación del relator y el mismo decano, por lo que, con todo, empezó la visita.

En primer término, el visitador revisó el archivo para ver los pleitos existentes. Recordemos que la cédula señalaba que se debía tomar "noticia del estado en que al presente está la dicha Audiencia, los pleitos que se trata en ella de qué calidad y cantidad son", a lo que el visitador indicó que lo primero 
que tuvo que hacer fue "[...] reducirlos a orden y forma los papeles de que hasta aquí carecía, por la suma incuria e ignorancia de los ministros que aquí le han manejado". ${ }^{39}$ Explicó el visitador que sacó en primer lugar los asuntos fiscales, donde incluyó las residencias, en total 206, las cuales remitió al fiscal para que las prosiguiese. Siguió con los del juzgado de difuntos, de los cuales, 115 estaban parados, y de los que no se adeudaban 26 mil pesos, por lo que procedió a que se cobraran. De los pleitos civiles y criminales refiere que eran 596 casos pendientes, tanto de poca como de mucha importancia.

El visitador, desde un principio, se decantó por la conservación de la Audiencia. Empezó su escrito contando la historia de su fundación desde Compostela, donde tuvo cuatro oidores alcaldes mayores, pasando por su dotación de presidente y sello real; pasó luego a señalar su jurisdicción actual (era el año 1638), indicando que ésta caía sobre dos reinos, Nueva Galicia y Nueva Vizcaya, y dio un aproximado de su tamaño al mencionar que

[...] desde esta ciudad de Guadalajara, corriendo del norte hasta la villa de San Felipe y Santiago que es cabecera de la provincia de Sinaloa, que actualmente se van descubriendo, hay poco más menos de doscientas leguas, y de la misma hasta la villa de Santiago de Saltillo hacia el oriente hay ciento y treinta, y a Culiacán y las Vírgenes que es el último de la Galicia hay más de otras doscientas, y a Topia, San Andrés, y Guanaceví y otras provincias de la Vizcaya, doscientas y cincuenta. $^{40}$

Ambos reinos comprendían, según dice el visitador, cuatro ciudades, 11 villas, 31 reales de minas y muchas poblaciones de naturales, y recordó que, además, por real cédula se le subordinaron cuatro provincias de Nueva España (Ávalos, Amula, Zapotlán y Autlán) donde había cuatro alcaldías mayores. Tenía además el presidente gobernador de la Nueva Galicia 35 oficios, y el gobernador de la Nueva Vizcaya muchos más. Para la fecha de la visita, la Audiencia conocía de todas las apelaciones de los jueces ordinarios, y para 1638 existían, como éste señalaba, 596 pleitos pendientes. Las razones de tan pocos pleitos eran, a entender del visitador, la pobreza de la tierra, la poca población de españoles y la poca población de naturales.

Sobre el puesto de la Audiencia en la ciudad de Guadalajara, éste creyó que era el más a propósito, ya que si bien las grandes distancias hacia el reino de la Vizcaya podían ameritar el cambio, como el obispo y los oficiales recomendaban, el reino de la Nueva Galicia excedía mucho en poblaciones y vecinos al de la Vizcaya, ya que dicho reino (el de Nueva Vizcaya), se reducía a la cabecera, que era Durango, “[...] lugar muy miserable y corto y a las minas

\footnotetext{
39 Ídem.

$40 \quad$ Ídem.
} 
de Parral [...]". En cambio, Guadalajara estaba en el centro, siendo equidistante de Zacatecas, Hostotipac, Lagos, Ávalos, Amula, Zapotlán, Autlán y Durango casi con igualdad, por lo que con esto se conseguía influir y administrar justicia a todos los vasallos con mayor comodidad. ${ }^{41}$

Una vez señaladas las distancias y la ubicación de la Audiencia, precisó el visitador que, para los vasallos de su Majestad, era mucho menos gravoso y mucho más barato que ir a México, ya que no se podía dejar de considerar que si tuvieran que ir a México los litigantes, les sería imposible despachar sus asuntos con rapidez; esto, porque la Audiencia de México “[...] está muy llena de negocios y embarazada de manera que amén de estar todos los jueces que tiene para dar expediente a los que ocurren, que siendo de mayor consideración y monto que los de la Galicia y entre personas más poderosas y válidas habían de tener prelación a estos [...]", por lo que los litigantes de Nueva Galicia se dilatarían en sus asuntos y los gastos de traslado y de mantenimiento en México serían muy cuantiosos. Esto no sucedería si la Audiencia se quedaba en Guadalajara, ya que como no había muchos negocios y sobraba tiempo, "[...] el litigante le haya oportuno para seguir su causa y acabarla sin dilación alguna $[\ldots] " .42$

Y es que, como añadió después, la Audiencia llevaba pocos casos, pero, de acuerdo con el visitador, esto no es lo único que hacía, ya que por distintas cédulas se le tenía encomendada la "[...] población y pacificación de la provincia, conversión de los naturales, labrar y cultura de las tierras que en primer lugar debiera y pudiera vacar y tender [...]"; y apuntó que

[...] tengo por cierto que la razón de faltar los dichos pleitos (principalmente los criminales), nace del miedo y respeto que a ella [la Audiencia] se tiene, pues este y su autoridad basta a en frenar en mucha parte a los delincuentes, gente vagabunda y facinerosa, de que estas provincias de toda la Nueva España abundan y principalmente el reino de la Vizcaya que como es potrero y límite de ella, es receptáculo de este género de gente que tiene por sagrado las minas de Parral como más apartadas de la Audiencia, de la cual huyen y se alejan, como de donde temen que les ha de venir la enmienda y el castigo [... ${ }^{43}$

Agregó también que, si la Audiencia se suprimía, ésta quedaría a merced de las autoridades religiosas, pues en este territorio, según el visitador " $[$...] los eclesiásticos y regulares y sus jueces aun se toman más licencia de lo que en otras partes acostumbran [...]", ${ }^{44}$ ya que, como se sabía, en su jurisdicción 
estaban dos obispados enteros y buena parte del de Michoacán, por lo que era demeritar la jurisdicción real el quitar la Audiencia, lo que hubiera sido en detrimento de los vasallos del rey.

También se expresó en contra de que se pusiera un gobernador, ya que según su experiencia de otros casos de gobernadores (especialmente el de Vizcaya), éstos eran más dados a la mala administración que las audiencias, ya que al ser sólo uno en el gobierno, esos no tenían quién los frenara.

Recordó, asimismo, al rey el gran daño que le haría a la ciudad de Guadalajara, ya que quitando la Audiencia ésta se despoblaría y los mercaderes y gentes se empobrecerían, como sucedió con la de ciudad de Compostela. Relató que, al quitarla, ésta se despobló y quedó en estado lamentable. Además, señaló que si bien su majestad se ahorraría los sueldos (que al año sumaban 18612 pesos, 3 tomines y 9 granos), tendría que pagarle al gobernador y a su teniente letrado; más grave aún, señalaba que se consumirían los oficios de todos los ministros que servían a la Audiencia que a la razón eran el alguacil mayor de corte, el escribano de cámara, sello y chancillería, el receptor de penas de cámara, cuatro procuradores y cinco receptores. Además, que su majestad quedaría obligado a devolver los pagos, entre otras complicaciones y juicios devenidos por esta decisión.

Finalmente, añadió que la experiencia había mostrado en los casos de la supresión de las audiencias de Filipinas y Chile las inconveniencias que esto ocasionó, y cómo tuvieron que volverlas a fundar. Le recordó a su majestad cómo en aquellas ocasiones se quitaron por las mismas razones que ahora se intentaba de quitar la de Guadalajara, "ociosidad y gasto", y sin embargo, aquéllas tenían una jurisdicción menor que ésta.

Una vez dadas sus impresiones y opiniones, claramente a favor de no suprimirla, el visitador pasó a señalar en seis capítulos las medidas que él sugería que podían combatir sus males si ésta se conservaba. Sugirió en primer lugar reformar la disposición de que, vacada la presidencia, el gobierno pasara a la Audiencia en su conjunto, ya que esto es lo que más graves daños había provocado en los últimos años. Propuso que, si esto ocurría, quedara el decano al mando de la institución, y recomendó encarecidamente que el nombramiento de presidentes tardara el menor tiempo posible, por lo que pidió que se nombraran como presidentes a los oidores de México para que ésta no quedara sin cabeza. Al final, el visitador señaló “[...] que el oidor más antiguo gobierne solo el tiempo todo que durare el venir del consejo el nuevo Presidente, que no que todos toquen el gobierno porque, aunque juzgo que las materias y causas de justicia se expiden y determinan mejor por muchos jueces, pero en las de gobierno, siempre seré de la opinión que ha de ser una cabeza el que las administre $[\ldots]]^{4}{ }^{45}$ 
La segunda propuesta fue que se cumpliera a cabalidad una cédula del 12 de diciembre de 1619 que prohibía la provisión de oficios a los parientes de los presidentes, oidores y fiscales, dado que una posterior de 20 de marzo de 1623 la dejó casi derogada.

$\mathrm{Su}$ tercera recomendación fue reformar las disposiciones para que los gobernadores no proveyeran en adelante provinciales de la hermandad, generales ni particulares, ya que, como indicó el visitador "[...] basta afirmar que es lo mismo pasar un juez de estos, rodeado de escribano y cuadrilleros por un partido que si llegase a él un ejército de langostas [...]". ${ }^{46}$

En cuarto lugar recomendó que se consumieran todos los oficios de corregidores y alcaldes mayores que estaban alrededor de la ciudad y a cinco leguas en contorno de ella, pues que al ser en su mayoría pueblos de indios, no era necesaria la asistencia de un juez español por los pocos delitos que había, y que la Audiencia podía cumplir esto con creces, conforme a las ordenanzas.

$\mathrm{Su}$ quinta recomendación fue que aquellos oficios que cesaran en las provincias por distintas causas, como por renuncia, venta o pérdida, fueran puestos en licitación con aprobación del presidente y gobernador, para evitar los traslados a México, las terceras partes y las largas vacancias.

Finalmente, propuso que se volviera a pedir a los obispos de estos lares, con mucho más énfasis, que cumplieran con la obligación de examinar a los curas tanto regulares como seculares, y tenerlos en la lengua de los naturales.

Dada por terminada la visita, volvió a relatar los atrevimientos y descortesías del oidor Medrano. Además, contó cómo cumplió cabalmente todo lo pedido y sus grandes sacrificios. De esta forma, una vez transcurridos los doscientos días que le dio de término el virrey, así como la prórroga de otros cien que había pedido y se le concedieron, éste le pidió ir a la Vizcaya a instalar y cobrar impuestos del 2\% para la fundación de la armada de Barlovento.

Sin embargo, el visitador, que ya no lo era, se rehusó a ir alegando mala salud y que el virrey ya no tenía jurisdicción sobre él, ya que la cédula sólo le concedía el nombramiento de visitador y nada más. Ante esto, el virrey le ordenó ir so pena de multa por 1000 ducados de Castilla y suspensión del oficio si no lo hacía. Pero el visitador no obedeció, por lo que el virrey le ordenó no salir de Guadalajara hasta que se resolviera la situación.

El visitador señaló sus impresiones sobre su situación, ya que acabada la visita y su autoridad "[...] solo me quedaba el nombre odioso de haberlo sido y la indignación de los poderosos quien había visitado", y remató con el sentimiento que le embargaba diciendo que "este, señor, fue el premio que me guardó a la obediencia que mostré en venir a esta ciudad y dejar mi casa, exponiendo mi salud tan contrariada de achaques a los riesgos de viaje tan 
largo y descomodidades de caminos, de esta tierra que aun en los que la tienen muy cabal se pueden y deben temer". ${ }^{47}$

Así, finalmente, el visitador pidió que se le hiciera justicia y se le permitiera volver a su plaza de oidor en México. Por documentos hallados, pudimos conocer que siguió como tal e incluso en 1647 se le promovió a Presidente de la Audiencia de Charcas, promoción que declinó.

\section{La PRIMERa DEliberación del ConSejo}

La información del visitador Rojas fue, sin duda alguna, la más autorizada y completa de las que le llegaron al consejo, ya que al año de su visita esta institución trató de tomar una determinación, por petición expresa del virrey duque de Escalona, quien en carta de 25 de noviembre de 1640 señaló que la Audiencia “causa más embargo que provecho", por lo que el Consejo de Indias decidió estudiar el caso en marzo de $1641 .{ }^{48}$ Como antecedentes se expusieron los siguientes:

Que los oidores desde 1629 estaban “[...] abanderizados dos a dos dándose la batalla pública y descompuestamente cada día en los estrados y fuera de ellos", y que incluso tras la llegada del presidente Morquecho siguieron las cosas como ya se ha visto, por lo que el Consejo de Indias recomendó quitar a los oidores más rijosos y mandarlos como supernumerarios a otras audiencias. De este modo, se decidió trasladar al licenciado Medrano a Santo Domingo y a al licenciado Villacreses a Panamá. En cuanto a Chávez, por no tener conflicto alguno, se quedaría en Guadalajara; sin embargo, esto no lo aceptó su majestad "[...] por ser plazas muy inferiores para tales ministros", de forma que no se actuó. Además, ya quedó dicho que murieron los tres entre 1630 y $1631 .{ }^{49}$

En mayo de 1632, el entonces virrey, Marqués de Cerralvo, también planteó la supresión de la Audiencia “[...] porque ahí tienen poco que hacer y se entretienen con discordias, que no han faltado desde que yo estoy en la Nueva España [...]". ${ }^{50}$ En 1634, se ordenó a los oidores obedecer al virrey y se mandó hacer una investigación por parte de éste, por el modo disoluto de vivir de los oidores, y de ello resultó una multa. Ese mismo año se recibieron quejas

$47 \quad$ Ídem.

48 Carta del duque de Escalona al rey de 25 de noviembre de 1640, en "Cartas de autoridades civiles y eclesiásticas, consultas, decretos, etc., relacionados en el Consejo sobre la conveniencia de suprimir la Audiencia de Guadalajara", AGI, GUADALAJARA, 10, R.4, N.19.

49 Deliberación del Consejo de Indias, en "Cartas de autoridades civiles y eclesiásticas, consultas, decretos, etc., relacionados en el Consejo sobre la conveniencia de suprimir la Audiencia de Guadalajara, AGI, GUADALAJARA, 10, R.4, N.19.

$50 \quad$ Ídem. 
del obispo de Guadalajara sobre la disconformidad de la Audiencia y sobre las grandes libertades que se tomaba para gobernar el reino. ${ }^{51}$

En 1635 se votó en el consejo y estuvieron en disconformidad los consejeros, unos a favor de la supresión y otros de una reformación. Sin embargo, se resolvió dejar las cosas como estaban y sólo llamarles la atención a los oidores. ${ }^{52}$ En 1636, se despachó un nuevo presidente, Juan de Canseco y Quiñones, con el cometimiento de poner en cintura a los oidores. ${ }^{53}$ En 1637, se ordenó la visita de la que ya dimos cuenta a un oidor de la Audiencia de México, y ya que Pedro de Quiroga falleció y luego sobrevino el temporal de lluvias, esta visita se retrasó hasta 1638 , año en que se mandó al oidor Francisco de Rojas. ${ }^{54}$

La decisión tomada por el Consejo, de momento, fue en buena medida gracias al informe del visitador, ya que su resolución resumió en buena medida lo dicho por el visitador:

[...] no conviene quitarla, porque si cuando se fundó pareció necesaria siendo entonces sus límites muy cortos, menos poblaciones y de pocos españoles, así entonces después se ha descubierto el reino de la nueva Vizcaya en sus provincias, y aumentando tanto o el de la Galicia, no parece que de convenir el consumirla. Tienen estos reinos de la Nueva Galicia y Vizcaya cuatro ciudades, once villas, treinta y un reales de minas, muchas poblaciones de naturales y estancias de españoles, y aun en el distrito de la nueva España por cédulas posteriores se le han su alternado cuatro provincias que son las de Ávalos, Amula, Zapotlán y la de Autlán en que hay cuatro alcaldías mayores considerables=en el gobierno de la Nueva Galicia hay 35 oficios a provisión del Presidente; en la de la Nueva Vizcaya hay otros muchos a la de aquel gobernador, las apelaciones de todas estas partes van a la Audiencia de Guadalajara, y hoy se hallan pendientes en ella quinientos y noventa y seis pleitos civiles y criminales, algunos de mucha y otros de menos importancia, la distancia de la jurisdicción es muy grande, y habiendo de ocurrir con las apelaciones a ella los vecinos, de los agravios que les hace los alcaldes mayores por ser gente pobre, aún se les hace grave la costa del camino y no lo pueden tolerar cuanto más se les haría en la ida a México que estaba casi cien leguas más lejos y la tierra por donde es para más carga y de mayor gasto, y lo que no se puede dejar de considerar que es que llegando los litigantes a México, no sería posible despachar sus causas a la brevedad que en Guadalajara porque en México está la Audiencia muy embarazada y llena de negocios de suerte que ha menester todo los jueces que tienen para dar expediente a los que ocurren, que siendo de mi mayor consideración que los de nueva Galicia, y entre personas más poderosas y validez habrán de tener la prelación fuera de que además de los

$\begin{array}{ll}{ }_{51} & \text { Ídem. } \\ { }_{52} & \text { Ídem. } \\ { }_{53} & \text { Ídem. } \\ { }_{54} & \text { Ídem }\end{array}$ 
pleitos, corren por cuenta de la Audiencia de Guadalajara otras muchas cosas como son, población, pacificación, conversión de los naturales, labor y cultura de las tierras, a que en primer lugar debiera y pudiera atender, y que tiene por cierto que la razón de faltar los pleitos criminales nace del respeto y miedo que aquella Audiencia le tiene, y a los particulares vecinos de Guadalajara le sería de mucho perjuicio ir a litigar a México[...]. sería muy damnificada la autoridad de la jurisdicción real, y que si esta Audiencia se reforma sería necesario un gobernador que administrase justicia. ${ }^{55}$

Además, se señaló que el cambio no sería bueno para la real caja, ya que, aunque se ahorrarían los 18612 pesos y mucho grano que se les daba a los oidores y al presidente, también se debía pagar al gobernador y a un teniente letrado, y se debía devolver lo pagado por los oficios vendibles que tenía la Audiencia (aunque dicho argumento parece un poco forzado, tomando en cuenta que tenían pocos compradores): alguacil mayor de corte, escribano de cámara, sello y canciller, receptor de penas de cámara, cuatro procuradores, cinco receptores. ${ }^{56}$

Finalmente no se pusieron de acuerdo, la razón fue el argumento de que, si en un origen así se determinó, era mejor que así siguieran las cosas. ${ }^{57}$ Por decisión real, no quedó más que esperar más informes de distintas autoridades, así como emitir la cédula de 12 de febrero de 1642 en donde el rey informó a su primo, el duque de Escalona, virrey de Nueva España que, toda vez que no se había determinado si se debía extinguir o no a la Audiencia de Guadalajara por faltar algunos informes,

[...] por ahora he proveído por presidente de aquella Audiencia al licenciado Pedro de Baeza, para que no esté tanto tiempo sin cabeza que la gobierne como conviene, y mientras esto se determina os encargo y mando veáis los papeles referidos que se entregaron al Marqués de Cadereyta, vuestro antecesor, y con particular atención y cuidado toméis muy individuales noticias de las cosas de aquellos Audiencia y sobre todo informéis con las razones de conveniencia o inconvenientes que hay en la materia con todos los fundamentos de ella en conformidad de lo que mande al dicho Marqués de Cadereyta y me remitáis esos informes con toda brevedad $[\ldots] .{ }^{58}$

Ídem.

Ídem.

Ídem.

Carta del rey al Conde de Salvatierra sobre el asunto de la Audiencia de Guadalajara, en "Cartas de autoridades civiles y eclesiásticas, consultas, decretos, etc., relacionados en el Consejo sobre la conveniencia de suprimir la Audiencia de Guadalajara", AGI, GUADALAJARA, 10, R.4, N.19. 
Parece que por algunos conflictos políticos externos (la anexión de Portugal por España), el virrey no pudo cumplir el mandato y fue su sucesor, el Conde de Salvatierra, quien contestó en una carta de 21 de febrero de 1645

He entendido que de muchos años a esta parte está reconocer la poca conveniencia y necesidad de la Audiencia de Guadalajara, y aunque por cédula del 12 de febrero de 1642 que repite otras antecedentes manda a mí y a esta de México se informe del estado de las cosas de aquella [...] la Audiencia de Guadalajara solo se ocupa en pelear y competir su ociosa jurisdicción en las materias de hacienda y guerra que VM tiene encargadas al virrey de esta Nueva España con tan escandalosos y arrojados sucesos como lo ha mostrado la experiencia [...] mientras se toma la resolución (que me parece ser a lo más conveniente quitar aquella Audiencia) mande VM advertir severamente a su Presidente en particular por lo mal que se ha procedido [...] para que ni sin estorbos se ponga y se cobren tantas deudas y se castiguen tantos delitos, remitiendo al virrey y al tribunal de cuentas las apelaciones. ${ }^{59}$

\section{EL INFORME DE LAS DEMÁS AUTORIDADES}

El fiscal de Guadalajara, el doctor Jerónimo de Alzate, se decantó el 12 de febrero de 1645 por la supresión de la Audiencia. Así lo expresó en un capítulo de carta, reiterando que en ella había muy pocos negocios, por lo que de ordinario sobraban las dos horas del tiempo de asistencia al que estaban obligados los oidores, sobre todo porque en reciente fecha se le habían suprimido al presidente la superintendencia de la hacienda y la de guerra, que le solían estar agregadas. Por tanto, opinó que lo más conveniente sería suprimirla y sujetarla a la de México, y recalcó que "[...] no hay fuerzas con qué llevar a debida ejecución las provisiones de VM que de justicia se ejecutarían". ${ }^{60}$

Tres años después, señaló en otro capítulo de carta del 28 de octubre de 1648 , como en diferentes ocasiones había referido a su majestad, que en la Audiencia había muy poco que hacer, y que en su opinión, convenía extinguirla y sujetarla a la Audiencia de México, y que si en caso contrario, se conservaba, se le encargara al presidente la superintendencia de la guerra y la de hacienda, para excusar ocasiones de competencias con los virreyes, ya que esto sería para "[...] gran consuelo y alivio a los vasallos de VM y las importancias de guerra y hacienda serían más propiamente asistidas". ${ }^{61}$

\footnotetext{
59 Ídem.

60 Carta del doctor Jerónimo de Alzate al rey del 12 de febrero de 1645, en "Cartas de autoridades civiles y eclesiásticas, consultas, decretos, etc., relacionados en el Consejo sobre la conveniencia de suprimir la Audiencia de Guadalajara", AGI, GUADALAJARA, 10, R.4, N.19.

61 Carta del doctor Jerónimo de Alzate al rey del 28 de octubre de 1648, en "Cartas de
} 
El oidor decano de Guadalajara, el licenciado Juan González Cid, quien tomó residencia al gobernador de Nueva Vizcaya, Luis de Valdés, en 1647, como juez visitador de esa tierra, además de encargarle que la apaciguara por una sublevación de la ciudad de Durango para con los oidores, dio su parecer en una carta del 6 de abril de 1649, en la que propuso la alternativa ya analizada y refutada por el visitador Rojas de pasar la Audiencia a la ciudad de Durango. Así, dio su parecer diciendo que convendría mudarla, ya que dicha ciudad estaba en medio y centro de las provincias de la Nueva Galicia, Nuevo Reino de León, Nuevo Reino de México, Sinaloa, Sonora y las Californias, por lo que sus poblaciones estarían más cercanas y se beneficiaría a los vasallos, ya que se les dificultaría menos el traslado para acudir a la Audiencia a tener remedio de sus agravios, así como obtener el "[...] amparo por las presiones en que los ponen los ministros inferiores y personas poderosas". Esto evitaría que se vieran obligados a ir a México, así que en su carta también relató que él había escuchado decir como argumento de tal mudanza que "[...] se mudó esta Audiencia de Compostela a Guadalajara para reducir y quietar a los indios de estas serranías que hacían cruel guerra con que se vino a conseguir el intento= está aquella ciudad de Durango en una comarca de muchas tierras montes y aguas para muy fértiles cosechas de trigo y maíz y otros frutos y cría de ganados $[\ldots]$ ".. ${ }^{62}$

Juan de Palafox y Mendoza, obispo de Puebla y Virrey interino, también dio su opinión a favor de la supresión, contestando a la dicha cédula, en una carta del 9 de enero de 1649, que a pesar de que en pasadas ocasiones en que el asunto sobre la extinción de la Audiencia se trató en el consejo, esto hacía más de veinte años, siempre fue del parecer que convenía su permanencia; sin embargo ahora había cambiado de opinión después de "[...] haberlo visto y reconocido en estas provincias y la situación de esta Audiencia y los pocos españoles y pleitos que hay en ella y las muchas discordias que se levantan y forman entre los virreyes y la Audiencia y los gobernadores de la Nueva Vizcaya". ${ }^{63}$ Finalmente, recalcó que los pocos pleitos que se formaban en aquel distrito y las poquísimas apelaciones podían fácilmente "[...] ocurrir

autoridades civiles y eclesiásticas, consultas, decretos, etc., relacionados en el Consejo sobre la conveniencia de suprimir la Audiencia de Guadalajara, AGI, GUADALAJARA, 10, R.4, N.19.

62 Carta del licenciado Juan González Cid al rey del 6 de abril de 1649, en "Cartas de autoridades civiles y eclesiásticas, consultas, decretos, etc., relacionados en el Consejo sobre la conveniencia de suprimir la Audiencia de Guadalajara, AGI, GUADALAJARA, 10, R.4, N.19.

63 Carta de Juan de Palafox y Mendoza al rey de 9 de enero de 1649, en "Cartas de autoridades civiles y eclesiásticas, consultas, decretos, etc., relacionados en el Consejo sobre la conveniencia de suprimir la Audiencia de Guadalajara", AGI, GUADALAJARA, 10, R.4, N.19. 
a la Audiencia de México, que no está más lejos en muchas partes que la de Guadalajara", ${ }^{64}$ y que esto ahorraría a su majestad una gran cantidad de agravios y de discordias, quitando de dicha Audiencia a "[...] ministros superfluos y poderosos", ${ }^{65}$ por lo que determinó "[...] que no solo es conveniente sino muy necesario el extinguirla". ${ }^{66}$

En la misma tónica, aunque un poco más prolijo, el Arzobispo de México, Juan de Mañozca y Zamora, se decantó por la supresión de la Audiencia en una carta del 12 de mayo de 1649, eso sí, "[...] tras consultar a personas entendidas y con experiencia", dando las siguientes razones: en primer lugar, señaló que la distancia no era ningún problema y dio cuenta de cómo Guadalajara, en su opinión, estaba muy cerca de México, y ya que los pleitos eran pocos y se dilataban en Guadalajara, bien podrían éstos acudir a México a pedir justicia con mayor comodidad, ya que al no ser vecinos de México serían atendidos con mayor justicia. Recalcó cómo las gentes podrían encontrar créditos para acudir a la Audiencia de México, ya que

[...] en esta ciudad tienen correspondencias de toda la Nueva España y así mismo los pobres que viniesen a seguir sus pleitos, sin más avío que traerlos, se entran en un carro de los muchos que van y vienen de tierras dentro a esta ciudad, como lo hacen los de Nuevo México, estando cuatrocientas leguas distantes a delante de Guadalajara, y el nuevo reino de León, y otras partes remotas, que vienen a esta ciudad, siguen su justicia y la alcanzan, con las comodidades [...]. ${ }^{67}$

En segundo lugar, argumentó que "[...] la Audiencia de Guadalajara, por los pocos pleitos que tiene, no sirve más que de causar litigios y revoluciones entre los vasallos de su VM, como se haya entre el Reino de la Nueva España y el de la Nueva Vizcaya [...]", ${ }^{68}$ y dio cuenta de distintos conflictos entre ambas, como lo fueron el pleito entre la Audiencia y el virrey Villamanrique a finales del siglo XVI y el problema con los gobernadores de Vizcaya de la década del 40 del siglo XVII. Finalmente, valoró que era de mucha conveniencia "[...] el consumir la dicha Audiencia de Guadalajara poniendo en su lugar un gobernador que gobierne todo lo que tocare a aquel obispado, con las apelaciones a esta corte, y en la nueva Vizcaya que el gobernador lo sea asimismo de lo que tocare al obispo de la dicha Nueva Vizcaya [...]". Con todo esto, el obispo

\footnotetext{
64 Ídem.

65 Ídem.

66. Ídem

67 Carta del Arzobispo de México Juan de Mañozca y Zamora al rey de 12 de mayo de 1649, en "Cartas de autoridades civiles y eclesiásticas, consultas, decretos, etc., relacionados en el Consejo sobre la conveniencia de suprimir la Audiencia de Guadalajara", AGI, GUADALAJARA, 10, R.4, N.19. Ídem.
} 
creía que los vasallos de aquella provincia gozarían de quietud y estarían “[...] libres de la neutralidad en que se hallan sobre que el de estas justicias han de obedecer con comodidades para poder los pobres y los ricos seguir con igualdad su justicia [...]". ${ }^{69}$ Esto muestra la visión del obispo un poco alejada de la realidad al creer que el viaje no era gravoso para los pobres, aunque su propuesta de hacer coincidir las jurisdicciones civiles y eclesiásticas no era del todo ajena a otras propuestas.

También la Audiencia de México fue consultada y esta fue la única institución, contra todo pronóstico, que defendió la existencia de su homónima. De tal manera lo hizo en carta del 23 de marzo de 1649, para preservar la existencia de la Audiencia de Guadalajara. La Audiencia de México abrió su carta, dividida en siete capítulos, señalando cómo el único fundamento que había motivado a los ministros (todos los antes señalados) para quitar la Audiencia de Guadalajara y que la sustituyera un gobernador fueron "[...] los pocos negocios que en ella hay, y que se podrían excusar el gasto de trece mil quinientos ducados [...]." Sin embargo, la Audiencia de México le recordó a su majestad cómo este mismo asunto se le propuso al señor Rey don Felipe segundo, y cómo dicho monarca "[...] se halagaba de que los pleitos fuesen pocos porque era señal que estaba el reino en paz y quería que se conservase dicha Audiencia para que se constase del buen tratamiento de los indios, y de aliar las fuerzas de los eclesiásticos $[\ldots]^{\prime \prime} .^{70}$

Su respuesta en defensa de su homónima, como señalábamos, se dividió en siete capítulos, muy al tono de las propuestas del licenciado Rojas diez años antes:

- En primer lugar, señaló que la Audiencia de Guadalajara tenía dentro de su distrito dos obispados (Guadalajara y Nueva Galicia) y gran parte del de Michoacán, por lo que, si se quitaba, padecerían mucho los vasallos, ya que " $[. .$.$] los indios que allí se hallan, son muy defendidos de la Audiencia,$ faltando este freno serían vejados gravemente, impartidos a las minas, que nunca se ha consentido en aquel distrito y a otros ministerios contra su voluntad y así se acabarían verdaderamente $[\ldots .]^{\prime 71}$

- El segundo argumento de la Audiencia era concerniente al poblamiento de la ciudad de Guadalajara, de apenas trescientos vecinos, de manera que la ciudad sólo se conservaba gracias a los ministros y dependientes de la dicha Audiencia "[...] y los demás que se sustentan a su calor y sombra

\section{9 Ídem.}

70 Carta de la Audiencia de México al rey de 23 de marzo de 1649, en "Cartas de autoridades civiles y eclesiásticas, consultas, decretos, etc., relacionados en el Consejo sobre la conveniencia de suprimir la Audiencia de Guadalajara", AGI, GUADALAJARA, 10, R.4, N.19.

$71 \quad$ Ídem. 
[...]" ${ }^{72}$ Así, si se quitaba, sin ninguna duda se despoblaría quedando sólo los prebendados de la iglesia y los oficiales reales.

- El tercer argumento fue el problema de tener que nombrar un gobernador, pues al ser temporal, darían ventajas y beneficios a sus familiares y amigos, sin tener oposición como la tenían los oidores entre ellos.

- El cuarto argumento fue lo extendido del reino y que las poblaciones eran lejanas entre sí, por lo que al llevar a la Audiencia una mayoría de casos menores, si estos se viniesen a México los vasallos preferirían no traerlos por los montos tan miserables.

- El quinto argumento fue que se requería quién controlara al corregimiento de Zacatecas y al gobernador de nueva Vizcaya, ya que si se iban las apelaciones a México sería muy difícil controlar a estas autoridades.

- El sexto argumento fueron los oficios vendibles, como lo eran el de alguacil mayor, escribanos, relatores, receptores de penas de cámara y procuradores, ya que al extinguirse la Audiencia debería pagarse por ellos.

- El séptimo argumento era, si acaso, una confirmación de la idea que se planteó al principio de la carta, y es que en la mentalidad de las autoridades de la época "[...] la causa que se tiene por más eficaz de la falta de los pleitos es el temor a la Audiencia y freno de saber que los delincuentes han de ser castigados y desagraviados los oprimidos y velados de las justicias inferiores".

Finalmente, la Audiencia de México pidió tomar en consideración dichos argumentos ya que "[...] no conviene quitar aquella Audiencia, mayormente que hoy se halla su distrito mucho más poblado que cuando se consultó a su majestad". ${ }^{73}$

Como se ve, la Audiencia de México siguió muy de cerca el informe del licenciado Rojas, por lo que sin duda lo tomó como ejemplo para dar el suyo; además, cabe destacar que algunos de los oidores firmantes de dicha carta fueron en su tiempo oidores de Guadalajara, como el licenciado Andrés Prado de Lago.

También la ciudad de Parral se pronunció. Esta no se mostró ni a favor ni en contra de la supresión de la Audiencia ${ }^{74}$ más bien pidió su independencia de Guadalajara para ser agregada a la jurisdicción de México, y rogó a su majestad que mandara que las apelaciones de Nueva Vizcaya fueran para la Audiencia de México, donde se hallaban los dos recursos, tanto el eclesiástico como el secular, así como también el conocimiento de hacienda y guerra, que estaba en manos de los virreyes. Argumentó, pues, que en México “[...] las 
personas miran con mucha mayor atención y afecto las cosas y negocios del servicio de VM y porque también ponen para la resolución y dirección de ellos la asistencia de mayores y más experimentados ministros [...]". Y es que la Audiencia de Guadalajara tenía para esas fechas todavía mucha aversión al gobernador de la Vizcaya, y las heridas de la "revuelta" de la década pasada todavía no sanaban entre ambas autoridades. Por supuesto, tenía razón en pedir certeza jurídica para saber a dónde pedir justicia y lo más lógico, como señalaba, era que fuera donde se encontraba el virrey, que conocía sobre guerra y hacienda.

Todo indica que se siguió la recomendación de la Audiencia de México y del visitador, ya que la idea de suprimir la Real Audiencia dejó de aparecer en las cédulas, y ésta continuó trabajando de la forma que estilaba. Sin embargo, a partir de la década de 1650 ya no hubo largas vacancias de presidentes, apenas unos meses, lo que hizo que disminuyeran los conflictos en buena medida.

Preguntar por qué se permitió que una Audiencia siguiera existiendo a 400 años de la decisión tomada por el Real Consejo pareciera ocioso; sin embargo, para el siglo XVII esto fue un hecho de la mayor preocupación para todas las autoridades tanto en América como en Europa, y el expediente sobre ello demuestra que en su mayoría los ministros consultados estaban a favor de su desaparición. Sin embargo, la visita del licenciado Rojas y la contestación de la Audiencia de México fueron las razones para su mantenimiento, y ambas coincidieron en que, si bien la Audiencia era "corta", era sumamente necesaria para mantener la "imagen de poder" en la región, que era lo que más importaba a la monarquía.

La Audiencia era la única institución capaz de mantener la paz, al menos en el imaginario de la época, pues quedaba como la única autoridad "letrada" en un territorio donde gobernaban los obispos, gobernadores, corregidores, alcaldes y encomenderos con total libertad a causa de la lejanía. La corona necesitaba una institución, por más pequeña, ociosa y costosa que ésta pareciera a ojos de los demás ministros, encabezada por burócratas leales y letrados en un territorio en vías de expansión y crecimiento, por lo que ese fue el argumento decisorio del Consejo de Indias: si la Audiencia de Nueva Galicia fue necesaria en el siglo XVI, cuando se creó, ¿cómo no iba serlo en el XVII, cuando ya era mucho más grande y estaba mucho más poblada?

\section{Bibliografía}

Arregui Zamorano, Pilar, La Audiencia de México según los visitadores (siglos XVI y XVII), México, UnAM, 1985.

Barrientos Grandon, Javier, Guía prosopográfica de la judicatura letrada indiana (1503-1898), Fundación Histórica Tavera, 2000. 
Berthe, Jean-Pierre; Calvo, Thomas y Águeda Jiménez Pelayo, Sociedades en construcción, la Nueva Galicia según las visitas de oidores (1606-1616), Guadalajara, México, Centro de Estudios Mexicanos y Centroamericanos, Universidad de Guadalajara (UDG), 2008.

DOI: https://doi.org/10.4000/books.cemca.1579

Calvo, Thomas, Poder, religión y sociedad en la Guadalajara del siglo XVII, México, 1991. DOI: https://doi.org/10.4000/books.cemca.3296

, La Nueva Galicia en los siglos XVI y XVII, Ma. de la Luz Ayala (trad.), Guadalajara, El Colegio de Jalisco, CEMCA, 1989.

, "Demografía y economía: la coyuntura en Nueva Galicia en el siglo xviı", Historia Mexicana, vol. 41, núm. 4 (164), abril-junio, 1992, p. 579.

—_, Guadalajara y su región en el siglo XVII, población y economía, Guadalajara 450 años, Guadalajara, 1992.

Calvo, Thomas y Aristarco Regalado (coords.), Historia del Reino de la Nueva Galicia, Guadalajara, UDG, 2016.

De la Mota Padilla, Matías, Historia del reino de Nueva Galicia en la América Septentrional, Guadalajara, IJAH-INAH, UDG, Colección histórica de obras facsimilares 3, 1973.

De Lázaro Arregui, Domingo, Descripción de la Nueva Galicia, François Chevalier (ed.), Sevilla, Escuela de Estudios Hispano-Americanos de la Universidad de Sevilla, 1946.

De Villadiego, Alonso, Instrucción política y práctica judicial conforme al estilo de los Consejos, Audiencias y Tribunales de Corte y otros ordinarios del Reino, Madrid, por Luis Sánchez, 1612.

De Zeballos, Jerónimo, Arte real para el buen gobierno de los reyes, y príncipes, y de sus vasallos, Madrid, 1623.

Diego-Fernández Sotelo, Rafael, La primigenia Audiencia de La Nueva Galicia 15481572. Respuesta al cuestionario de Juan de Ovando por el oidor Miguel Contreras y Guevara, Zamora, El Colegio de Michoacán, 1994.

Elizondo, Francisco Antonio, Práctica universal forense de los Tribunales de esta Corte, Reales Chancillerías de Valladolid y Granada y Audiencia de Sevilla su origen, jurisdicción, y negocios de que conoce cada uno, con inhibición de los demás, Madrid, Joachin Ibarra, 1764.

García Marín, José María, La justicia del Rey en Nueva España, Córdoba, Universidad de Córdoba, 2011.

Malagón Pinzón, Miguel, “Las visitas indianas, una forma de control de la administración pública en el estado absolutista”, Universitos, núm. 108, diciembre, 2004, pp. 821-838.

Mantilla Trolle, Mariana del Sagrario, Audiencia de Guadalajara. Siglo XVIII, Guadalajara, Editorial Universitaria, UDG, 2015.

Mazin Gómez, Oscar (ed.), México en el mundo Hispánico, Zamora, El Colegio de Michoacán, 2000.

Muro Romero, Fernando, Las presidencias-gobernaciones en Indias (siglo XVI), Madrid, Editorial CSIC, 1975. 
Ots y Capdequí, José María, El estado español en las Indias, México, Fondo de Cultura Económica, 1993.

Parry, John H., La audiencia de Nueva Galicia en el siglo XvI, Zamora, El Colegio de Michoacán, 1993.

Peñaloza H., Guillermo, El derecho de indias y su metrópoli, Bogotá, Temis, 1969.

Pérez Landero Otáñez y Pedro Castro, Práctica de visitas y residencias apropiada á los Reynos del Perú y deducida de lo que en ellos se estila. Nápoles, 1696. Disponible en http://bdhrd.bne.es/viewer. vm?id=0000038309\&page=1 [consultado el 01 de octubre de 2018]. Sánchez Bella, Ismael, "El juicio de visita en Indias”, IV Congreso del Instituto Internacional de Historia del Derecho Indiano, México, 1976, pp. 579-626.

- Derecho Indiano. Estudios: Las visitas generales en la América española (siglos XVI-XVII), vol. I, Eunsa, 1991.

—- Derecho indiano. Estudios: Fuentes. Literatura Jurídica. Derecho Público, vol. II, Eunsa, 1991.

Schäfer, Ernesto, El Consejo Real y Supremo de las Indias. Su historia, organización y labor administrativa hasta la terminación de la Casa de Austria, vol. II, Sevilla, 1947.

Soberanes Fernández, José Luis, Los tribunales en la Nueva España, México, UNAM, 1980.

Vicente Martín, Luis, Los Orígenes de la Audiencia Real Castellana, Universidad de Sevilla, 1997. 